\title{
COMPARATIVE STUDY BETWEEN UNDERLAY AND OVERRLAY TECHNIQUE IN TYPE 1 TYMPANOPLASTY IN CSOM MUCOSAL INACTIVE TYPE
}

\section{ENT}

\section{Dr. Chandpreet Kour}

\section{Dr. Saima}

Tabassum*
Junior Resident, ENT Department of ENT- Maharishi Markandeshwar Institute Of Medical Sciences And Research, Mullana,(Distt-Ambala),Haryana, India

Senior Resident, ENT Department of ENT- Maharishi Markandeshwar Institute Of Medical Sciences And Research, Mullana,(Distt-Ambala),Haryana, India. *Corresponding Author

\section{Dr. Madeha Drabu Junior Resident-ENT India}

\section{ABSTRACT}

Otitis Media (OM) is an inflammatory condition which usually involves muco-periosteal covering of middle ear cleft (partial or full) comprising of eustachain tube (ET), hypo-tympanum, meso-tympanum, epi-tympanum, additus and the mastoid air cells.

Myringoplasty was introduced by Berthold5 long back in 1878 and included the surgical closure of tympanic membrane perforation including removal of epithelium and grafting with skin. This period witnessed an improvement in surgical techniques with improved optics and emergence of microsurgery, thus making the Myringoplasty safer and lowered the rate of graft rejection. In this study we have compared the the grafting technique in type-1 tympanoplasty of in CSOM mucosal inactive type.

\section{KEYWORDS}

Underlay, Overrlay, Tympanoplasty

\section{INTRODUCTION}

Otitis Media $(\mathrm{OM})$ is an inflammatory condition which usually involves muco-periosteal covering of middle ear cleft (partial or full) comprising of eustachain tube (ET), hypo-tympanum, mesotympanum, epi-tympanum,additus and the mastoid air cells.

All age groups are affected and there are multiple factors contributing to it. The most common being infections, ET dysfunction, allergy in the nose and trauma. OM is classified pathologically into following types ${ }^{2}$ :
(a) Mucosal (active or inactive)
(b) Squamosal (active or inactive)
(c) Chronic (healed)

ET dysfunction when chronic and accompanied by secondary negative middle ear pressure is a frequent cause of perforation as well as recurrent atelectasis. Cholesteatoma may or may not be present. Reconstruction is done using fascia or perichondrium to reserve the anatomy and functional status of tympanic membrane. ${ }^{3}$ The process is known as Tympanoplasty. It is a surgery performed not only for reconstructing Tympanic membrane but also the ossicles of the middle ear.

Wullestein ${ }^{4}$ was the person who first coined the term Tympanoplasty and used split thickness graft for the same.

The aim of repairing the perforation is:

(a) Normal/ non restricted social life of patient which also includes any issue related to water entry.

(b) To correct the hearing loss occurred due to perforation.

Types of tympanoplasty as described by Wullstein ${ }^{4}$ :

(a) Type I: Also called myringoplasty and only involves the examination of tympanic cavity and restoration of the perforated eardrum by grafting.

(b) Type II: Ossicular chain partially destroyed but preserved and continuity restored. Graft lay against the ossicles after removal of the bridge.

(c) Type III: Myringostapediopexy producing a shallow middle ear and a columella effect.

(d) Type IV: Round window protection with a small middle ear mobile footplate left exposed.

(e) Type V: Closed middle ear with round window protection; fenestra in the horizontal semicircular canal covered by a graft.

Myringoplasty was introduced by Berthold ${ }^{5}$ long back in 1878 and included the surgical closure of tympanic membrane perforation including removal of epithelium and grafting with skin. This period witnessed an improvement in surgical techniques with improved optics and emergence of microsurgery, thus making the Myringoplasty safer and lowered the rate of graft rejection.

The grafting technique which have been compared in this study are as follow:

1 Overlay technique:the graft is placed lateral to the annulus or the remnant of tympanic membrane and only the epithelial layer is elevated. In this technique anterior meatal recess is $\mathrm{b}$ etter visualized so can be used for anterior perforations extending into anterior annulus.

2 Underlay technique graft is placed medial to annulus or manubrium of malleus, ideal for small or posterior perforation and is relatively easier to perform.

The concept of placing the graft medial to annulus was given by Shea and Tabb in $1960^{\circ}$.

\section{METHODAND MATERIAL:}

The study was conducted in 82 patients The study cohort included patients who had a central perforation with no discharge for 6 weeks or more and were followed up for at least till 6 months after the surgery.

Patients in which the procedure was contraindicated, for example, those having cholesteatoma,ossicular chain dysfunction sensinural hearing loss, patients less that 10 years of age or those not medically fit for the operation due to chronic systemic diseases were not included

Also, patients in which infection stemmed from extra aural sites like that in sinusitis, recurrent tonsillitis, nasal obstruction .From the patients undergoing the surgery, a written informed consent was taken.

A detailed history was taken and clinical examination was performed. All patients were subjected to pure tone audiometry, within 3 months of the procedure.

Besides these, tuning fork test, microscopic examination of ear, Xray of mastoid and CT of temporal bones were done, along with regular preoperative laboratory investigations.

For the purpose of this study, in all the patients, the surgery was done under GA by a post auricular approach and for the graft, temporalis facia was used.

Techniques used for the purpose of this study include underlay and overlay techniques

The patient may be discharged in a day or two. They are advised to keep the ear dry and to avoid blowing their nose vigorously and sneeze with mouth open to minimise straining. Patients are called for regular follow-up every two weeks initially and then monthly, for six months. Merocel is removed in the first post op visit, that is, after 1 week of surgery. A pure tone audiometry is performed 3 months after surgery. 
The data was assimilated considering various variables like gender of the patient, age, type and size of perforation, surgical method used, and complications if any.

\section{RESULTS}

The study was conducted between time duration of December 2017 to December 2018 total of 82 patients were included in the study. Group A(underlay) comprised of 40 cases $(48.78 \%)$ and on the other side group $\mathrm{B}$ (overlay) consist of 42 cases(51.22\%).Patients age ranged from 16 and 51 years in group A whereas in Group B age ranged between 17 and 48 years. The mean age in Group $\mathrm{A}$ being 32.22years(standard deviation 9.22) whereas in group B mean age ranged between 31.78 years(standard deviation 8.64).By means of ANOVA the $p$ value between the mean age of patients in both groups came to be 0.824 which was statistically insignificant.

$47.5 \%$ (19 cases )left ear was involved and 52.5\%(21 cases) right ear was involved in group $\mathrm{A}$.

$38.09 \%$ (16 cases) left ear was involved and61.9\%(26 cases) right ear was involved in group B

Unilateral ear involved $77.5 \%$ ( 31cases) whereas bilateral ear was involved in $22.5 \%$ ( 9 cases $)$ in group A.

Whereas in group B unilateral ear involvement was in $83.3 \%$ (35 cases) and $16.7 \%$ ( 7 cases) in group B.

The preoperative ABgap in Group A was 11-20db in 8 cases, 21-30db in 17 cases, $31-40 \mathrm{db}$ in 15 cases. The preoperative ABgap in Group B was $11-20 \mathrm{db}$ in 7 cases, $21-30 \mathrm{db}$ in 16 cases,31-40db in 19 cases. (Table-1)

The mean AB gap in group A was $25.57 \mathrm{db}(\mathrm{SD} 6.68)$ and in Group B the mean $\mathrm{AB}$ gap was $28.96 \mathrm{db}(\mathrm{SD} 6.45) \mathrm{p}$ value being 0.34 on comparaing the mean preopearative $\mathrm{AB}$ gap which was statistically insignificant.

The success rate of graft intake in group A was $92.5 \%$ (37 cases) and 85.72 (36 cases in group A.The failure rate was $7.5 \%$ ( 3 cases ) in group A and $14.28 \%$ (6 cases ) in group B. On comparing the graft uptake rate in both the groups the $p$ value came out be 0.52 which was statistically insignificant (Table-2)

Postoperative $\mathrm{AB}$ gap $<10 \mathrm{db}$ was observed in 5 patients, $11-20 \mathrm{db}$ in 19 patients, $21-30 \mathrm{db}$ in 16 patients and no case was seen between 31-40 $\mathrm{db}$ in group A on the other hand in group B $<10 \mathrm{db}$ was found in 6 cases, $11-20 \mathrm{db}$ in 17 cases,21-30 db in 18 cases and 31-40 db was observed in 1 case. The mean postoperative $\mathrm{AB}$ gap improved to $17.58 \mathrm{db}$ (SD 5.79 )in group A. whereas in group $B$ postoperative $A B$ gap improved to $19.17 \mathrm{db}(\mathrm{SD} 7.01)$.p value between two groups being 0.26 which was statistically insignificant.(Table-3)

Table-1: Pre-op audiological asessment ABG

Decibel Pre-Op Audiological Asesement Abg (db)

\begin{tabular}{|c|c|c|c|c|c|c|}
\hline & \multicolumn{3}{|c|}{\begin{tabular}{|l|} 
Group A \\
\end{tabular}} & \multicolumn{3}{|l|}{ Group B } \\
\hline & Numbe & $\begin{array}{l}\text { Percentage } \\
\%\end{array}$ & $\begin{array}{l}\text { Group } \\
\text { Total }\end{array}$ & Number & $\begin{array}{l}\text { Percentage } \\
\%\end{array}$ & $\begin{array}{l}\text { Group } \\
\text { Total }\end{array}$ \\
\hline \begin{tabular}{|l|}
$11-20$ \\
\end{tabular} & 8 & 20.00 & 40 & 7 & 16.67 & 42 \\
\hline $21-30$ & 17 & 42.5 & & 16 & 38.09 & \\
\hline $31-40$ & 15 & 37.5 & & 19 & 45.24 & \\
\hline$>40$ & 0 & 0 & & 0 & 0 & \\
\hline
\end{tabular}

Table-2: Graft uptake (follow up-3 months)

\begin{tabular}{|l|l|l|l|l|l|l|}
\hline \multirow{2}{*}{} & \multicolumn{5}{|c|}{ GRAFT UPTAKE } \\
\cline { 2 - 7 } & \multicolumn{2}{|l|}{ Group A } & \multicolumn{3}{|l|}{ Group B } \\
\cline { 2 - 7 } & Positive & Negative & $\begin{array}{l}\text { Total } \\
\text { Case }\end{array}$ & Positive & Negative & $\begin{array}{l}\text { Total } \\
\text { Case }\end{array}$ \\
\hline Numbers & 37 & 3 & 40 & 36 & 6 & 42 \\
\hline Percentage & 92.5 & 7.5 & $100 \%$ & 85.72 & 14.28 & $100 \%$ \\
\hline
\end{tabular}

Table 3: Post-operative audiological asessment ABG gain.

Decibel Post-op audiological asesement abg gain(db)

\begin{tabular}{|c|c|c|c|c|c|c|}
\hline & \multicolumn{3}{|c|}{ Group A } & \multicolumn{3}{|c|}{ Group B } \\
\hline & Numbe & Percentage $\%$ & \begin{tabular}{|l|} 
Group \\
Total
\end{tabular} & Number & Percentage $\%$ & \begin{tabular}{|l|} 
Group \\
Total
\end{tabular} \\
\hline$<10$ & 5 & 12.5 & 40 & 6 & 14.28 & 42 \\
\hline $11-20$ & 19 & 47.5 & & 17 & 40.48 & \\
\hline $21-30$ & 16 & 40 & & 18 & 42.86 & \\
\hline $31-40$ & 0 & 0 & & 1 & 2.38 & \\
\hline
\end{tabular}

DISCUSSION

In our study, 82 cases in the age group varying from 15-50 years and both gender with normal functioning ET ,dry ear for last 4 weeks with single large central perforation were taken from Otorhinolaryngology Department of MMIMSR, Ambala. Complete detailed history, clinical assessment of the patients and all routine investigations were performed. Pre-operatively Pure Tone Audiometry was done to determine the type and degree of deafness. In the follow-up period of 3 months again post operatively audiometry was performed to access the degree of hearing gain.

Glasscock ${ }^{7}$ (1976)said that young age was a relative contraindication for the surgical intervention since children less than 3 to 4 years of age are most susceptible to recurrent upper respiratory tract infection and frequent episodes of $\mathrm{OM}$.

Wullstein $^{8}$ was the first who used the term tympanoplasty. It included all the procedures undertaken for reconstruction of hearing mechanism impaired by chronic ear disease.

In 1952, Wullstein was the first top use split thickness skin graft so as to close the perforation. One year later Zollner ${ }^{9}$ also used the similar graft material.

\section{In 1963,Zollner used fascia lata as graft material to close perforation.}

Parmod Kalsotra et $\mathrm{al}^{10}$ in 2017 a study between overlay and underlay stated that underlay technique was slightly better with the graft uptake rate of $91.43 \%$ and mean postoperative $\mathrm{AB}$ gap of $11.11 \mathrm{db}$ as compared to the overlay technique in which the graft uptake rate was $89.18 \%$ and mean post-operative $\mathrm{AB}$ gap of $11.72 \mathrm{db}$.

In a study conducted by shahpoue kouhpaei ${ }^{11}$ he concluded hearing improvement was $83.8 \%$ with overlay technique and $64.5 \%$ with underlay technique he also stated that hearing improvement was better with overlay technique.

In a study by Ashfaq ${ }^{12}$ et al in 2004 .reported a success rate of graft uptake of $73 \%$ in 105 cases by underlay technique of tympanoplasty.

In 19995 Khan and Khan ${ }^{13}$ in study of 94 cases reported $77.5 \%$ of successful graft uptake by underlay technique.

In a study conducted by $\mathrm{Fadl}^{14}$ in 2003 his results were $85.4 \%$ success with underlay technique of tympanoplasty and $66.7 \%$ successful graft uptake by overlay technique.

Ortegren ${ }^{15}$ in 1964 presented a paper on the result of myringoplasty which was carried out since 1957 by various otologists like Zollner, Wright, Heerman et al etc. based on the extensive study he concluded that connective tissue grafts are superior to skin graft material and the results of myringoplasty done on patient above 40 years were not so good as those below this limit. Also noticed that re-perforations occurred before 6 months in most cases at follow up .He introduced the term myringoplasty

Wehrs ${ }^{16}$ and others observed that an aerated middle year space is a precondition to achieve a positive post-operative outcome from tympanoplasty. Poor ET function is the most common cause of inadequate aeration of middle ear post tympanoplasty. Other contributing factors include middle ear adhesions, loss of support of the posterior canal wall and inadvertent blockage of the ET orifice by graft material. Aeration of the mastoidectomy cavity is also important to prevent collapse of the posterior canal wall, retraction pockets and ensure an adequate air reserve.

In our present study sucessfull intake of graft with underlay technique $92.5 \%$ was slightly better than overlay techn ique of myringoplasty which was $85.72 \%$ but it was stasistically insignificant $p$ value 0.52 .

complication rate was slightly lower in group A as compared to group B 1 case of graft lateralization was seen in group A whereas 2 case of graft medialization was seen in group B

\section{CONCLUSION}

Evaluating our study in the light of present literature we emphasize that both the techniques of underlay and overlay showed good results in term of hearing improvement but graft uptake rate was slightly higher 
with underlay technique as the graft is well supported medially by the mucosal layer and is relatively simple and less time consuming.

\section{REFERENCES}

1. 1 Chavan S, Deshmukh S, Pawar V, Kirpan V, Khobragade S, Sarvade K. Tympanoplasty with and without cortical mastoidectomy for tubotympanic type of chronic suppurative otitis media. Otolaryngol Head Neck Surg.2011; 8(1):8-10.

2. Browning GG, Merchant SN, Kelly G, Swan RC, Canter R, Mckerrow WS. Chronic Otitis Media. In: Gleeson M, Browning GG, Burton MJ, Clarke RW, John Hibbert, Jones NS, Lund VJ, Luxon L, Watkinson JC. Scott-Brown's Otorhinolaryngology, Head and Neck Surgery. 7th edition. London: Edward Arnold Publishers Ltd; 2008; 3 : 3395-3401

3. Yu-HsuanWen,Lee-Ping Hsu, Peir-Rong Chen, Chia-Fone Lee. Design optimization of cartilage myringoplasty using finite element analysis. Tzuchi Med J 2006; 18(5): 37077.

4. Wullstein H. Tympanoplasty. In: Glasscock ME and Shambaugh GE. Surgery of the Ear. 5th (ed). India: Hamilton, Elsevier; 2003:466.

5. Berthold E Ueber,Myringoplastik, Wier Med Bull,1878,1,627-627.GlasscockShambaugh.Surgery of the ear.5th (ed)463-486,BC Decker Inc,2003.

6. Shea JJ(1960) vein graft closure of ear drum perforation.J laryngol otol 74:358 Tabb HG (1960) Closure of perforation of tympanic membrane by vein grafts.Laryngoscope 73:699 Tabb HG(1968)Experience in transcanal and postauricular myringoplasty.Tran Pac Coast Oto Opthalmol Soc Arnn Meet 52:121:125

7. Glasscock ME. Contraindications to tympanoplasty II: an exercise in clinical judgment. Laryngoscope. 1976; 86:70-76.

8. Wullstein H. Tympanoplasty. Glasscock ME and Shambaugh GE. Surgery of the Ear. 5th (ed.) India: Hamilton, Elsevier; 2004:400.

9. Zollner F. Panel myringoplasty second workshop on reconstructive middle ear surgery.Arch Otol.1963;78:301.

10. Kalsotra P, Gupta R, Gupta N, Kotwal S, Suri A, Kanotra S. Overlay versus underlay myringoplasty: A comparative study. Indian J Otol 2014:20(4):183-188.

11. KouhpaeiS. The comparative study of underlay and overlay tympanoplasty without chain reconstruction effect on the improvement of hearing loss and tympanic landmarks among patients with otitis media.Exp Rhinol Otolaryngol 2018:2(1):105-109.

12. Ashfaq M, Aasim MU, Khan N. Myringoplasty: Anatomical and functional results. Pak Armed Forces Med J. 2004;54(2):155-8.

13. Khan IZ, Khan MA. Tympanoplasty at combined military hospital Rawalpindi. Pak Armed Forces Med J .1995;45:33-5.

14. Fadl FA. Outcome of type-1 tympanoplasty. Saudi Med J. 2003;24(1):58-61

15. Ortegren. Myringoplasty. Acta Otolaryngology. Four years of experience with Temporalis Fascia Graft. 1964; 193: 1-43.

16. Wehrs RE, Tulsa OK. Aeration of the middle ear and mastoid in tympanoplasty. Laryngoscope. 1981;91: 1463-67. 